Jurnal Ekonomi Pembangunan

Volume 11, Nomor 1, Juni 2010, hlm.1-12

\title{
FLYPAPER EFFECT PADA PENGELUARAN PEMERINTAH DAERAH DI JAWA
}

\author{
Bambang Agus Pramuka \\ Fakultas Ekonomi Universitas Jenderal Soedirman \\ Jalan HR. Boenyamin Nomor 708 Purwokerto Jawa Tengah, Telp: (0281) 635292
}

Diterima 20 Nopember 2009/Disetujui 15 April 2010

\begin{abstract}
This study analysis whether there is any flypaper effect in local governments' expenditures, and whether there are significant influences of grants from central government and original revenue of local governments on their expenditures, especially the operating and capital expenditures. The object of the study are all local autonomous governments in Java; and the focus of the study was the financial statement of the 2005-2008 fiscal year. Through an examination on financial statement of all kabupatens and kotas in Java, and applying multiple regression analysis, it is revealed that the flypaper effect was not found, which implied that the local government did not rely more on grant from the central government as the sources of their budget. The DAU (grant) and PAD (original revenues), however, were found to be significantly influencing the operating, capital, and total of local government expenditures, for the related year and the following year.
\end{abstract}

Keywords: flypaper effect, DAU, PAD, capital expenditure, operating expenditure

\begin{abstract}
Abstrak: Penelitian ini menganaliis apakah ada flypaper effect dalam pengeluaran pemerintah daerah, dan apakah ada pengaruh yang signifikan dari hibah dari pemerintah pusat dan pendapatan asli pemerintah daerah pada pengeluaran mereka, terutama pengeluaran operasional dan modal. Obyek dari penelitian ini adalah semua pemerintah daerah otonom seperti kabupaten dan kota di Jawa, dan pusat perhatian penelitian adalah laporan keuangan tahun fiskal 2005-2008. Melalui pemeriksaan atas laporan keuangan dari semua kabupaten dan kota tersebut di Jawa, dan menerapkan analisis regresi berganda, terungkap bahwa flypaper effect tidak ditemukan, yang menyiratkan bahwa pemerintah setempat tidak mengandalkan hibah dari pemerintah pusat sebagai sumber dari anggaran mereka. DAU (hibah) dan PAD (pendapatan asli), bagaimanapun, terbukti secara signifikan mempengaruhi operasi, modal, dan total pengeluaran pemerintah daerah, untuk tahun yang bersangkutan dan tahun berikutnya.
\end{abstract}

Kata kunci: flypaper effect, DAU, PAD, belanja modal, belanja operasional

\section{PENDAHULUAN}

Otonomi daerah yang diterapkan di Indonesia hingga saat ini merupakan wujud dari desentralisasi yang selaras dengan diberlakukannya UU No. 32 Tahun 2004 pasal 1 ayat 2 yang menyatakan bahwa pemerintahan daerah adalah penyelenggaraan urusan pemerintahan oleh pemerintah daerah dan DPRD menurut asas otonomi dan tugas pembantuan dengan prinsip otonomi seluas-luasnya dalam sistem dan prin- sip Negara Republik Indonesia sebagaimana dimaksud dalam Undang-Undang Dasar Negara Republik Indonesia Tahun 1945. Sedangkan Pasal 1 ayat 5 menyatakan bahwa otonomi daerah adalah hak, wewenang, dan kewajiban daerah otonom untuk mengatur dan mengurus sendiri urusan pemerintahan dan kepentingan masyarakat setempat sesuai dengan peraturan perundang-undangan.

Implikasi langsung atas implementasi otonomi daerah adalah kebutuhan dana yang cu- 
kup besar sebagai modal awal menuju kemandirian pemerintah daerah. Sumber dana utama pemerintah daerah berasal dari PAD yang dipakai untuk membiayai belanja modal dan pembangunannya. Namun dalam beberapa tahun berjalan sumber pembiayaan daerah tidak hanya berasal dari PAD saja. Pemerintah daerah juga mendapatkan bantuan transfer dana dari pemerintah pusat berupa Dana Perimbangan. Berdasarkan UU No. 33 Tahun 2004 Dana Perimbangan terdiri dari Dana Bagi Hasil (DBH), Dana Alokasi Umum (DAU), dan Dana Alokasi Khusus (DAK). Tujuan dari transfer ini adalah untuk mengurangi atau menghilangkan kesenjangan fiskal antarpemerintah dan menjamin tercapainya standar pelayanan publik minimum di seluruh provinsi.

Daerah yang mempunyai kemampuan fiskal rendah akan mendapatkan DAU dalam jumlah yang relatif besar, sebaliknya daerah yang mempunyai kemampuan fiskal tinggi akan mendapatkan DAU dalam jumlah yang kecil. Pemberian DAU ini diharapkan dapat mengurangi disparitas fiskal horisontal, sehingga daerah mempunyai tingkat kesiapan fiskal yang relatif sama dalam mengimplementasikan otonomi daerah. Daerah diharapkan mampu mengalokasikan sumber dana ini pada sektor-sektor produktif sehingga dapat mendorong peningkatan investasi di daerah dan juga pada sektor yang berdampak pada peningkatan pelayanan publik serta dapat meningkatkan kontribusi publik terhadap PAD. Hal ini diharapkan agar kemandirian daerah menjadi semakin tinggi seiring dengan meningkatnya kapasitas fiskal daerah, yang menyebabkan tanggungan pemerintah untuk memberikan DAU bisa lebih dikurangi.

Permasalahan yang terjadi saat ini adalah pemerintah daerah terlalu menggantungkan alokasi DAU untuk membiayai belanja modal dan pembangunan tanpa mengoptimalkan potensi yang dimiliki oleh daerah. Bukti-bukti empiris secara internasional menunjukkan bahwa tingginya ketergantungan pada transfer ternyata berhubungan negatif dengan hasil governansinya. Hal ini berarti pemerintah daerah akan lebih berhati-hati dalam menggunakan dana yang digali dari masyarakat sendiri dibandingkan dengan dana transfer dari pe- merintah pusat (Kuncoro, 2007:3).

Di saat transfer DAU yang diperoleh besar, maka pemerintah daerah berusaha agar pada periode berikutnya DAU yang diperoleh tetap. Hal ini menyebabkan PAD tidak signifikan berpengaruh terhadap Belanja Daerah yang menyebabkan terjadinya flypaper effect atau dapat dikatakan bahwa pengaruh DAU terhadap Belanja Daerah lebih besar daripada pengaruh PAD terhadap Belanja Daerah. Dengan arti lain pemberian DAU yang seharusnya menjadi stimulus peningkatan kemandirian daerah, justru direspon berbeda oleh daerah. Daerah tidak menjadi lebih mandiri, malah semakin bergantung pada pemerintah pusat (Ndadari dan Adi. 2008:3).

Karena itulah peneliti ingin mengetahui bagaimana pengaruh sebenarnya DAU dan PAD terhadap Belanja Daerah dan apakah terjadi flypaper effect terhadap Belanja Daerah pada Pemerintah Daerah Kabupaten dan Kota di Pulau Jawa. Dua hal yang dapat terjadi pada penelitian ini adalah terjadi atau tidaknya flypaper effect pada pengaruh DAU dan PAD terhadap belanja daerah. Jika penelitian ini mengindikasikan telah terjadi flypaper effect pada Belanja Daerah, maka pemerintah daerah diharapkan untuk meninjau ulang kebijakan yang telah diterapkan agar dapat mengeksplor secara maksimal pendapatan yang bersumber dari daerah sebagai bentuk kemandirian dari daerah tersebut.

Tujuan penelitian ini adalah untuk memberikan bukti empiris tentang pengaruh secara simultan dan parsial dari DAU dan PAD terhadap Belanja Pemerintah Kabupaten dan Kota di Jawa; membuktikan ada-tidaknya flypaper effect pada belanja daerah Pemerintah Kabupaten dan Kota di pulau Jawa; membuktikan kecenderungan DAU dan PAD menyebabkan peningkatan jumlah belanja daerah di tahun berikutnya; dan membuktikan kecenderungan $\mathrm{DAU}_{\mathrm{t}-1}$ dan $\mathrm{PAD}_{\mathrm{t}-1}$ menyebabkan peningkatan pengeluaran belanja operasi atau belanja modal.

Manfaat penelitian dilihat baik dari segi teori maupun terapan antara lain sebagai masukan dan tambahan referensi bagi pihakpihak yang ingin mengambil penelitian dan studi pustaka tentang keuangan daerah serta 
menjadi bahan evaluasi tentang kebijakan keuangan daerah bagi pemerintah daerah khususnya dan kota di Jawa khususnya, dan Indonesia umumnya.

Flypaper effect atau lebih dikenal dengan efek kertas layang adalah suatu kondisi yang terjadi saat pemerintah daerah merespon (belanja) lebih banyak dengan menggunakan dana transfer (grants) yang diproksikan dengan DAU dari pada menggunakan kemampuan sendiri, diproksikan dengan PAD (Maimunah, 2006:9). Karena itu flypaper effect dianggap sebagai suatu anomali dalam prilaku rasional jika transfer harus dianggap sebagai tambahan pendapatan masyarakat (seperti halnya pajak daerah), sehingga harus dibelanjakan dengan cara yang sama pula dengan pendapatan asli daerah. Fenomena flypaper effect membawa implikasi lebih luas bahwa transfer akan meningkatkan belanja pemerintah daerah lebih besar daripada penerimaan transfer itu sendiri. Anomali yang timbul tersebut menghasilkan dua aliran pemikiran dari para pengamat ekonomi mengenai telaah flypaper effect, yakni Model Birokratik (bureaucratic model) dan Model Ilusi Fiskal (fiscal illusion model)

Pemikiran birokratik berpandangan posisi birokrat lebih kuat dalam pengambilan keputusan publik dimana berusaha untuk memaksimalkan anggaran sebagai proksi kekuasaannya. Model birokratik juga menegaskan flypaper effect sebagai akibat dari perilaku birokrat yang leluasa untuk membelanjakan transfer daripada menaikkan pajak. Shinta (2009: 37) menyatakan bahwa "implikasi yang penting dari model ini bahwa desentralisasi fiskal memacu pertumbuhan sektor publik. Dalam sistem yang terdesentralisasi, pemerintah daerah memiliki lebih banyak informasi untuk membedakan kepentingan penduduknya sehingga bisa memperoleh lebih banyak sumber daya dari perekonomian. Sehingga efisiensi ekonomi penyediaan barang publik akan tercapai dengan melibatkan partisipasi masyarakat".

Model Ilusi Fiskal (fiscal illusion model) pertama kali dikemukakan oleh ekonom Italia bernama Amilcare Puviani yang menggambarkan ilusi fiskal terjadi saat pembuat keputusan yang memiliki kewenangan dalam suatu institusi menciptakan ilusi dalam penyusunan keuangan (rekayasa) sehingga mampu mengarahkan pihak lain pada penilaian maupun tindakan tertentu. Maksud dari penjelasan di atas dalam konteks penelitian ini adalah pemerintah daerah melakukan rekayasa terhadap anggaran agar mampu mendorong masyarakat untuk memberikan kontribusi lebih besar dalam hal membayar pajak atau retribusi, dan juga mendorong pemerintah pusat untuk mengalokasikan dana dalam jumlah yang lebih besar.

Apabila terdapat respon yang asimetris terkait dengan penerimaan maupun pengeluaran maka dapat diindikasikan terjadi ilusi fiskal. (Shinta, 2009: 38)

Dana Alokasi Umum (DAU). DAU merupakan dana hibah murni (grants) yang kewenangan penggunaanya diserahkan penuh kepada pemerintah daerah penerima. UU No. 33 tahun 2004 tentang Perimbangan Keuangan antara Pemerintah Pusat dan Daerah memberikan pengertian bahwa DAU adalah dana yang bersumber dari pendapatan APBN yang dialokasikan dengan tujuan untuk pemerataan kemampuan keuangan antar daerah, untuk mendanai kebutuhan daerah dalam rangka pelaksanaan desentralisasi. DAU merupakan sarana untuk pemerataan kemampuan keuangan antar daerah yang dimaksudkan untuk mengurangi ketimpangan kemampuan keuangan antar daerah melalui penerapan formula yang mempertimbangkan kebutuhan dan potensi daerahnya. Pemberian DAU lebih diprioritaskan pada daerah yang mempunyai kapasitas fiskal rendah dimana daerah tersebut belum mampu memaksimalkan pendapatan asli daerahnya dikarenakan suatu hal. Untuk daerah yang mempunyai kapasitas fiskal tinggi justru akan mendapat jumlah DAU yang lebih kecil, sehingga diharapkan dapat mengurangi ketidakseimbangan fiskal antardaerah dalam menjalani era otonomi sekarang.

UU No. 33 Tahun 2004 pasal 27 menetapkan jumlah kebutuhan DAU ditetapkan sekurang-kurangnya 26 persen dari Pendapatan Dalam Negeri Neto yang ditetapkan dalam APBD. UU No. 33 Tahun 2004 pasal 29 menambahkan proporsi DAU antara provinsi dan kabupaten/kota ditetapkan berdasarkan imbangan kewenangan antara provinsi dan kabupaten/kota. DAU diprioritaskan penggunaan- 
nya untuk mendanai gaji dan tunjangan pegawai, kesejahteraan pegawai, kegiatan operasi dan pemeliharaan serta pembangunan fisik sarana dan prasarana dalam rangka peningkatan pelayanan dasar dan pelayanan umum yang dibutuhkan masyarakat.

Pendapatan Asli Daerah (PAD). Menurut UU No. 33 Tahun 2004 pasal 1 ayat 18 menyatakan bahwa PAD adalah pendapatan yang diperoleh Daerah yang dipungut berdasarkan Peraturan Daerah sesuai dengan peraturan perundang-undangan. Kelompok PAD dipisahkan menjadi empat jenis pendapatan, yaitu: Pajak Daerah, Retribusi Daerah, Hasil perusahaan milik daerah dan hasil pengelolaan kekayaan milik daerah yang dipisahkan, serta LainLain PAD yang sah

Belanja Daerah. Menurut UU No. 33 Tahun 2004 pasal 1 ayat 14, Belanja Daerah (BD) adalah semua kewajiban Daerah yang diakui sebagai pengurang nilai kekayaan bersih dalam periode tahun anggaran yang bersangkutan. Pengeluaran belanja berbeda dengan pengeluaran pembiayaan. Perbedaan tersebut terletak pada ada atau tidaknya pengembalian dana yang telah dikeluarkan. Pemerintah daerah tidak akan mendapatkan pembayaran kembali atas pengeluaran belanja yang terjadi, baik pada tahun anggaran berjalan maupun pada tahun anggaran berikutnya. Sedangkan pengeluaran pembiayaan merupakan pengeluaran yang akan diterima kembali pembayarannya pada tahun anggaran berjalan atau pada tahun anggaran berikutnya.

Menurut Peraturan Pemerintah nomor 24 tahun 2005 tentang Standar Akuntansi Pemerintahan, struktur Belanja Daerah yang digunakan dalam APBD diklasifikasikan menurut klasifikasi ekonomi, yaitu: Belanja Operasi (BO); Belanja Modal (BM), dan Belanja Tidak Terduga. Belanja operasi adalah pengeluaran anggaran untuk kegiatan sehari-hari pemerintah daerah yang memberikan manfaat jangka pendek. Belanja operasi terdiri dari: Belanja Pegawai, Belanja Barang, Belanja Bunga, Belanja Subsidi, Belanja Hibah, dan Belanja Bantuan Sosial. Belanja modal merupakan pengeluaran yang dianggarkan untuk pembelian atau pengadaan aset tetap dan aset lainnya untuk digunakan dalam kegiatan pemerintahan yang memiliki kriteria sebagai berikut: masa manfaatnya lebih dari 12 bulan, merupakan objek pemeliharaan, jumlah nilai rupiahnya material sesuai dengan kebijakan akuntansi. Belanja modal terdiri dari belanja tanah; belanja peralatan dan mesin; belanja gedung dan bangunan; belanja jalan, irigasi dan jaringan; belanja aset tetap dan lainnya; dan belanja aset lainnya. Belanja Tidak Terduga adalah pengeluaran anggaran untuk kegiatan yang sifatnya tidak biasa dan tidak diharapkan berulang seperti penagnggulangan bencana, bencana sosial dan pengeluaran tidak terduga lainnya yang sangat diperlukan dalam rangka penyelenggaraan kewenangan pemerintah pusat/daerah. Belanja tidak terduga antara lain meliputi belanja penanganan bencana dan belanja pelaksanaan kewenangan.

Pengaruh DAU Terhadap Belanja Daerah. DAU merupakan sumber pendapatan yang penting bagi sebuah daerah dalam memenuhi pengeluarannya. Besarnya DAU yang diterima oleh pemerintah daerah dapat menunjukkan tingkat kemandirian suatu daerah. Semakin banyak DAU yang diterima maka daerah tersebut masih bergantung kepada Pemerintah Pusat yang menandakan bahwa daerah tersebut belum mandiri dan belum siap menjadi daerah otonom seperti yang tertuang dalam UU NO. 32 Tahun 2004 tentang Pemerintahan Daerah. Begitu juga sebaliknya, semakin sedikit DAU yang diterima maka daerah tersebut mandiri dan siap menghadapi otonomi.

Pengaruh PAD terhadap Belanja Daerah. PAD merupakan sumber pendapatan penting bagi sebuah daerah dalam memenuhi belanjanya. Besarnya PAD yang diterima oleh pemerintah daerah dapat menunjukkan tingkat kemandirian suatu daerah. Semakin banyak PAD yang didapat semakin memungkinkan daerah tersebut untuk dapat memenuhi kebutuhan belanjanya sendiri tanpa harus tergantung pada Pemerintah Pusat, Ini menunjukan bahwa pemerintah daerah tersebut telah mampu untuk mandiri dan menjadi daerah otonom.

Pengaruh Flypaper Effect pada Prediksi Belanja Daerah. Widodo (2007:35) memberikan penjelasan bahwa dalam sebuah proses penyusunan anggaran ada sebuah teori yang dikenal dengan istilah incrementalism. Sistem penganggaran Incrementalism adalah sistem pengang- 
garan yang hanya menambah atau mengurangi jumlah rupiah pada item-item anggaran yang sudah ada sebelumnya dengan menggunakan data tahun sebelumnya sebagai dasar untuk menyesuaikan besarnya penambahan atau pengurangan. Incrementalism juga terjadi pada penyusunan Belanja Daerah ditahun berikutnya dimana pemerintah daerah berusaha menambah atau mengurangi jumlah rupiah pengeluaran dan PAD yang diterima agar dana transfer yang diterima konstan dengan tahun sebelumnya atau malah bertambah.

Hipotesis. Berdasarkan landasan teori yang telah dikemukakan sebelumnya, maka hipotesis penelitian ini adalah:

$\mathbf{H}_{\mathbf{1}}$ adalah DAU dan PAD secara simultan dan parsial berpengaruh signifikan terhadap Belanja Pemerintah Kabupaten dan Kota di pulau Jawa. $\mathbf{H}_{\mathbf{2}}$ adalah terjadi flypaper effect pada Belanja Daerah.

$\mathbf{H}_{3}$ adalah Flypaper effect cenderung menyebabkan peningkatan jumlah Belanja Daerah di tahun berikutnya.

$\mathbf{H}_{4}$ adalah kecenderungan peningkatan pengeluaran yang terjadi pada belanja operasi atau belanja modal di tahun berikutnya.

\section{METODE PENELITIAN}

Penelitian ini mengambil lokasi Kabupaten dan Kota di pulau Jawa.Obyek penelitian ini adalah laporan Realisasi Anggaran Penerimaan dan Belanja Daerah (APBD) pemerintah kabupaten dan kota di pulau Jawa. Populasi yang menjadi bahan penelitian ini adalah laporan keuangan daerah yang tersebar seluruh kabupaten dan kota di pulau Jawa. Seluruh pemerintah kabupaten dan kota se Jawa dijadikan sampel penelitian (sampel jenuh), kecuali provinsi Banten dan DKI Jakarta, dengan periode pengamatan tahun anggaran 2005 sampai 2008.

Jenis data yang akan diteliti adalah data sekunder, berupa catatan atau laporan historis yang telah tersusun dalam arsip (data dokumenter) yang dipublikasikan dan yang tidak dipublikasikan. Data penelitian bersumber dari laporan keuangan daerah kabupaten dan kota di pulau Jawa. Data yang diambil hanyalah data laporan keuangan yang telah dipublikasi- kan dalam rentang tahun 2001-2008. Data diperoleh dari situs resmi Badan Pemeriksa Keuangan (www.bpk.go.id.) dan Kementerian Dalam Negeri (www.depdagri.go.id). Metode pengumpulan data dalam penelitian ini yaitu Studi Pustaka dan Dokumentasi, yaitu memanfaatkan data dari buku-buku atau media massa dengan tujuan untuk memperoleh referensi, serta dengan cara meminta data yang telah ada sebelumnya.

Untuk menguji hipotesis yang diajukan, data dianalisis dengan menggunakan analisis regresi berganda (multiple regression) dengan menggunakan Software SPSS. Untuk menguji keberartian koefisien regresi secara simultan dilakukan uji-F, sedang untuk menguji pengaruh secara parsial dilakukan uji-t. Model regresi untuk uji hipotesis I adalah:

$B D=a+b_{1} D A U_{t}+b_{2} P A D_{t}+e$

Kriteria penerimaan hipotesis II menurut Maimunah (2006:12), “Untuk dapat dikatakan telah terjadi flypaper effect maka hasil yang diperoleh haruslah menunjukkan nilai koefisien DAU lebih besar dari nilai koefisien PAD dan keduanya signifikan atau PAD tidak signifikan.

Untuk menguji apakah Flypaper effect cenderung menyebabkan peningkatan jumlah Belanja Daerah dapat menggunakan regresi berganda, persamaan yang dapat digunakan dalam pengujian hipotesis III adalah sebagai berikut:

$B D=a+b_{1} D A U_{t-1}+b_{2} P A D_{t-1}+e$

Pengujian Hipotesis IV. Menurut Peraturan Pemerintah nomor 24 tahun 2005 tentang Standar Akuntansi Pemerintahan, struktur Belanja Daerah yang digunakan dalam APBD diklasifikasikan menurut klasifikasi ekonomi, hal inilah yang menyebabkan peneliti ingin mengetahui kecenderungan peningkatan pengeluaran lebih ke Belanja Operasi atau ke Belanja Modal. Untuk menguji apakah peningkatan pengeluaran cenderung terjadi pada Belanja Operasi atau Belanja Modal dapat menggunakan analisis regresi berganda. Persamaan regresi yang adalah sebagai berikut: 
$B O=a+b_{1} D A U_{t-1}+b_{2} P A D_{t-1}+e$

$B M=a+b_{1} D A U_{t-1}+b_{2} P A D_{t-1}+e$

\section{HASIL DAN PEMBAHASAN}

\section{Pengaruh PAD dan DAU terhadap Belanja Daerah Tahun yang Sama}

Persamaan regresi yang diperoleh sebagai berikut:

$$
\begin{aligned}
B D= & 5079,91301+1,966800 P A D+ \\
& 1,127870 D A U+e
\end{aligned}
$$

Dari persamaan tersebut dapat dinyatakan bahwa:

Nilai konstanta sebesar 5079,91301 artinya apabila PAD dan DAU dalam keadaan nol maka Belanja Daerah sebesar Rp5.079.913.010.

Koefisien regresi variabel PAD sebesar $+1,966800$ artinya jika variabel lain dalam keadaan konstan, maka nilai rata-rata kenaikan satu juta rupiah PAD akan mengakibatkan kenaikan sebesar Rp1.966.800 dalam Belanja Daerah.

Koefisien regresi variabel DAU sebesar $+1,127870$, artinya jika variabel lain dalam keadaan konstan, maka nilai rata-rata kenaikan satu juta rupiah DAU akan mengakibatkan kenaikan sebesar Rp1.127.870 dalam Belanja Daerah.

\section{Pengaruh PAD dan DAU terhadap Belanja Daerah tahun berikutnya}

Persamaan regresi yang diperoleh adalah sebagai berikut:

$$
\begin{aligned}
B D_{t}= & 86903,0264+2,18126179 P A D_{t-1}+ \\
& 1,18615999 D A U_{t-1}+e
\end{aligned}
$$

Dari persamaan tersebut dapat dinyatakan bahwa:

Nilai konstanta sebesar 86903.0264 artinya apabila $\mathrm{DAU}_{\mathrm{t}-1}$ dan $\mathrm{PAD}_{\mathrm{t}-1}$ (tahun lalu) dalam keadaan nol maka Belanja Daerah tahun ini $\left(\mathrm{BD}_{\mathrm{t}}\right)$ akan surplus sebesar Rp86.903.026.400.

Koefisien regresi variabel $\mathrm{PAD}_{\mathrm{t}-1}$ sebesar 2.18126179 artinya jika variabel lain dalam keadaan konstan, maka nilai rata-rata kenaikan satu juta rupiah pada PAD $_{\mathrm{t}-1}$ (tahun lalu) akan mengakibatkan kenaikan sebesar Rp2.181.262 dalam Belanja Daerah tahun ini $\left(\mathrm{BD}_{\mathrm{t}}\right)$.

Koefisien regresi variabel $\mathrm{DAU}_{\mathrm{t}-1}$ sebesar 1.18615999 , artinya jika variabel lain dalam keadaan konstan, maka nilai rata-rata kenaikan satu juta rupiah pada $\mathrm{DAU}_{\mathrm{t}-1}$ (tahun lalu) akan mengakibatkan kenaikan sebesar Rp1.186.160 dalam Belanja Daerah tahun ini $\left(\mathrm{BD}_{\mathrm{t}}\right)$.

\section{Pengaruh PAD dan DAU terhadap Belanja Operasi tahun berikutnya}

Persamaan regresi yang diperoleh adalah sebagai berikut:

$$
\begin{aligned}
B O_{t}= & 26415,5419+1,76250463 P A D_{t-1}+ \\
& 1,01915959 D A U_{t-1}+e
\end{aligned}
$$

Dari persamaan tersebut dapat dinyatakan bahwa:

Nilai konstanta sebesar 26415.5419 artinya apabila $\mathrm{PAD}_{\mathrm{t}-1}$ dan $\mathrm{DAU}_{\mathrm{t}-1}$ (tahun lalu) dalam keadaan nol maka Belanja Operasi tahun ini $\left(B O_{t}\right)$ akan surplus sebesar Rp26.415.541.900.

Koefisien regresi variabel $\mathrm{PAD}_{\mathrm{t}-1}$ sebesar 1,76250463 artinya jika variabel lain dalam keadaan konstan, maka nilai rata-rata kenaikan satu juta rupiah pada $\operatorname{PAD}_{\mathrm{t}-1}$ (tahun lalu) akan mengakibatkan kenaikan sebesar Rp1.762.505 dalam Belanja Operasi tahun ini $\left(B O_{t}\right)$.

Koefisien regresi variabel $\mathrm{DAU}_{\mathrm{t}-1}$ sebesar 1.01915959 , artinya jika variabel lain dalam keadaan konstan, maka nilai rata-rata kenaikan satu juta rupiah pada $\mathrm{DAU}_{\mathrm{t}-1}$ (tahun lalu) akan mengakibatkan kenaikan sebesar Rp1.019.160 dalam Belanja Operasi tahun ini $\left(B O_{t}\right)$.

\section{Pengaruh PAD dan DAU terhadap Belanja Modal tahun berikutnya}

Persamaan regresi yang diperoleh adalah sebagai berikut:

$$
\begin{aligned}
B M_{t}= & 60528,3949+0,42247717 P A D_{t-1}+ \\
& 0,16226750 D A U_{t-1}+e
\end{aligned}
$$

Dari persamaan tersebut dapat dinyatakan bahwa:

Nilai konstanta sebesar 60528.3949 artinya apabila PAD $_{\mathrm{t}-1}$ dan $\mathrm{DAU}_{\mathrm{t}-1}$ (tahun lalu) dalam 


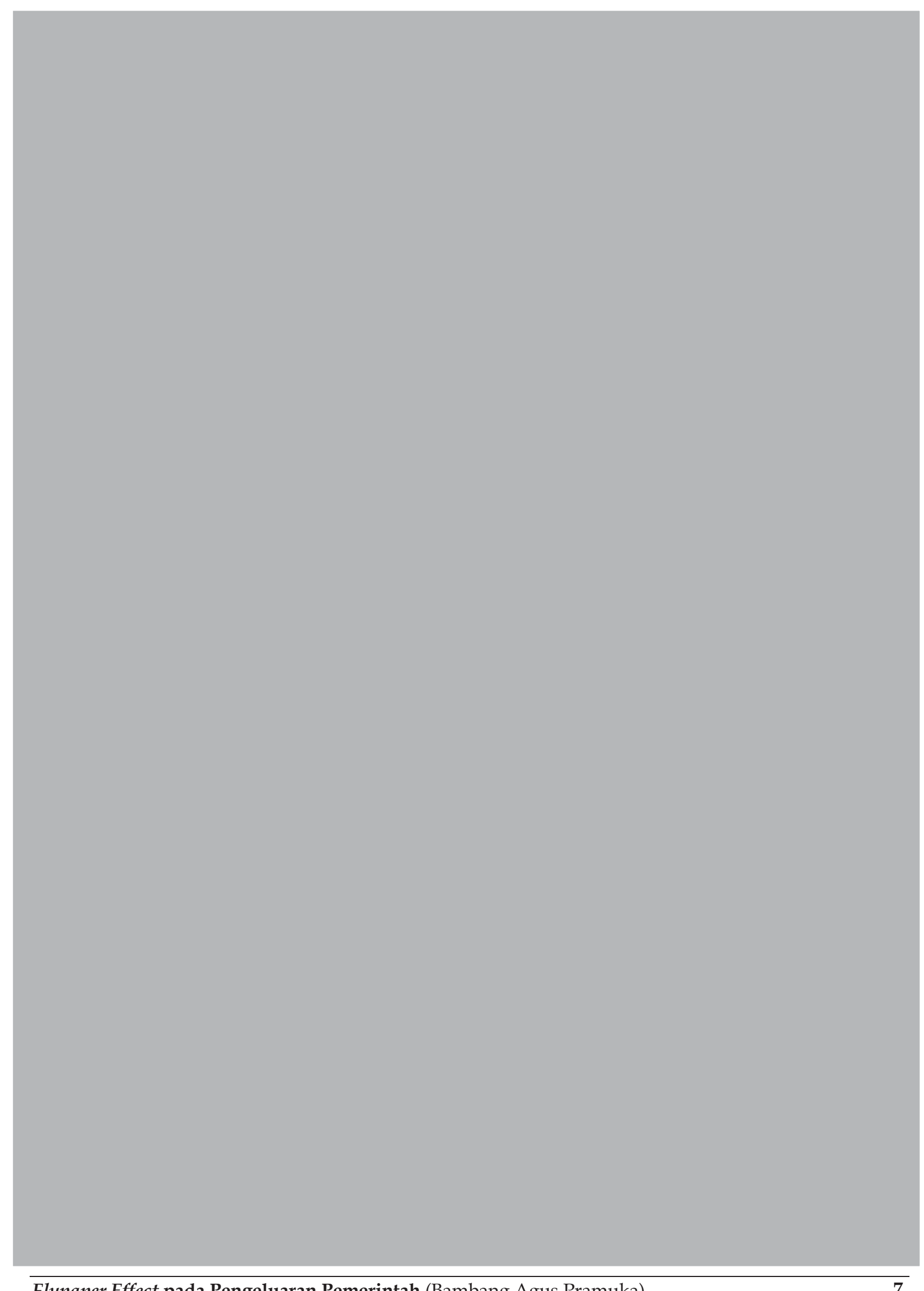

Flypaper Effect pada Pengeluaran Pemerintah (Bambang Agus Pramuka) 
merintah daerah tidak mengoptimalkan pendapatan asli daerahnya dalam menunjang pengeluaran pemerintah daerah.

Hasil penelitian ini berbeda dengan hasil penelitian terdahulu yang dilakukan oleh Maimunah (2006: 11) yang menyatakan bahwa terdapat keterikatan yang sangat erat antara transfer dari Pemerintah Pusat dengan Belanja Daerah. Hal serupa juga dinyatakan oleh Ndadari dan Adi (2008: 16) bahwa besarnya PAD suatu daerah dipengaruhi oleh besarnya alokasi DAU. Bisa jadi ada kecenderungan pemerintah daerah enggan untuk menggali potensi daerahnya karena mereka merasa belanja daerah sudah cukup dibiayai dengan DAU saja. Adi (2007: 13-14) dalam penelitiannya juga menemukan bahwa daerah yang ditelitinya masih mempunyai ketergantungan yang tinggi terhadap transfer pemerintah pusat dibandingkan mengoptimalkan pendapatan asli daerahnya, atau terdapat kecenderungan ketika DAU yang diterima semakin tinggi maka upaya pajak pemerintah kabupaten atau kota justru semakin rendah. Hal serupa juga dinyatakan oleh Wijaya (2008: 66) dan Novianingsih (2009) dimana dana perimbangan dalam hal ini termasuk DAU merupakan variabel yang lebih besar pengaruhnya terhadap belanja daerah daripada pendapatan asli daerah tersebut.

Hipotesis II digunakan untuk membuktikan terjadinya flypaper effect pada Belanja Daerah. Dari hasil penelitian (Lampiran) menunjukkan bahwa nilai Unstandardized Coefficients DAU $(1,128)$ TIDAK lebih besar dari nilai Unstandardized Coefficients PAD $(1,967)$ dan keduanya berpengaruh signifikan terhadap Belanja Daerah; artinya, TIDAK terjadi flypaper effect pada Kabupaten dan Kota di Jawa. Artinya bahwa dana alokasi dari pemerintah pusat hanya berfungsi untuk membantu pemerintah daerah dalam menunjang pendapatan asli daerahnya. Pemerintah daerah tidak menggantungkan pengeluaran daerahnya kepada dana alokasi umum, sehingga sejalan dengan maksud tujuan awal pemerintah pusat memberikan bantuan dana.

Kesimpulan ini berbeda dengan hasil penelitian di beberapa Kabupaten secara sendiri-sendiri maupun kelompok, misalnya di kabupaten se eks karesidenan Banyumas, yang berkesimpulan terjadinya flypaper effect pada anggaran kabupaten-kabupaten di eks karesidenan Banyumas (Al-Firsta \& Pramuka, 2010). Kuncoro (2007: 22) dalam penelitiannya juga mengemukakan bahwa dana alokasi dari pemerintah pusat menjadi penghalang bagi pemerintah daerah untuk meningkatkan PAD. Yang ada justru pemerintah daerah berupaya bagaimana caranya dana alokasi yang diterima dari tahun ke tahun tetap atau meningkat. Wijaya (2008: 66) dan Maimunah (2006: 11) dalam penelitiannya mempunyai persamaan pendapat mengenai temuan adanya ketergantungan pemerintah daerah terhadap dana transfer dari pemerintah pusat, yang merupakan suatu kondisi yang terjadi pada saat pemerintah daerah merespon belanja lebih banyak dengan menggunakan dana transfer daripada menggunakan kemampuan sendiri. Penelitian oleh Ndadari dan Adi (2008: 17) yang didukung oleh penelitian dari Shinta (2009: 78) juga menyatakan bahwa terjadi flypaper effect pada dana alokasi umum yang membuktikan bahwa terjadi kecenderungan perilaku asimetris pemerintah daerah terhadap transfer pemerintah pusat.

Hipotesis III dalam penelitian ini menemukan bahwa meskipun tidak terdapat flypaper effect, $\mathrm{DAU}_{\mathrm{t}-1}$ dan $\mathrm{PAD}_{\mathrm{t}-1}$ berpengaruh positif terhadap $\mathrm{BD}_{\mathrm{t}}$; yang berarti $\mathrm{DAU}_{\mathrm{t}-1}$ dan $\mathrm{PAD}_{\mathrm{t}-1}$ cenderung menyebabkan peningkatan jumlah Belanja Daerah di tahun berikutnya. Hal ini menandakan pemerintah daerah menggunakan anggaran laporan keuangan terdahulu untuk menentukan besarnya pengeluaran pemerintah daerah di tahun yang akan datang sekaligus menganggarkan besarnya dana alokasi dan pendapatan asli daerahnya. Hal ini sesuai dengan peneliti terdahulu dimana $\mathrm{DAU}_{\mathrm{t}-1}$ dan $\mathrm{PAD}_{\mathrm{t}-1}$ berpengaruh positif terhadap $\mathrm{BD}_{\mathrm{t}}$. Widodo (2007: 54) mengemukakan $\mathrm{DAU}_{\mathrm{t}-1}$ berpengaruh positif terhadap $\mathrm{BD}_{\mathrm{t}}$ yang berarti dalam jangka panjang transfer dari pemerintah pusat berpengaruh terhadap belanja daerah. Sementara untuk PAD $_{\mathrm{t}-1}$ berpengaruh positif terhadap $\mathrm{BD}_{\mathrm{t}}$, Widodo (2007: 55) kembali menjelaskan bahwa kenaikan dalam pajak akan meningkatkan belanja daerah sehingga akhirnya akan memperbesar defisit. Ini disebabkan karena PAD atau juga pajak adalah penerimaan yang diperoleh dari sumber dalam wilayahnya 


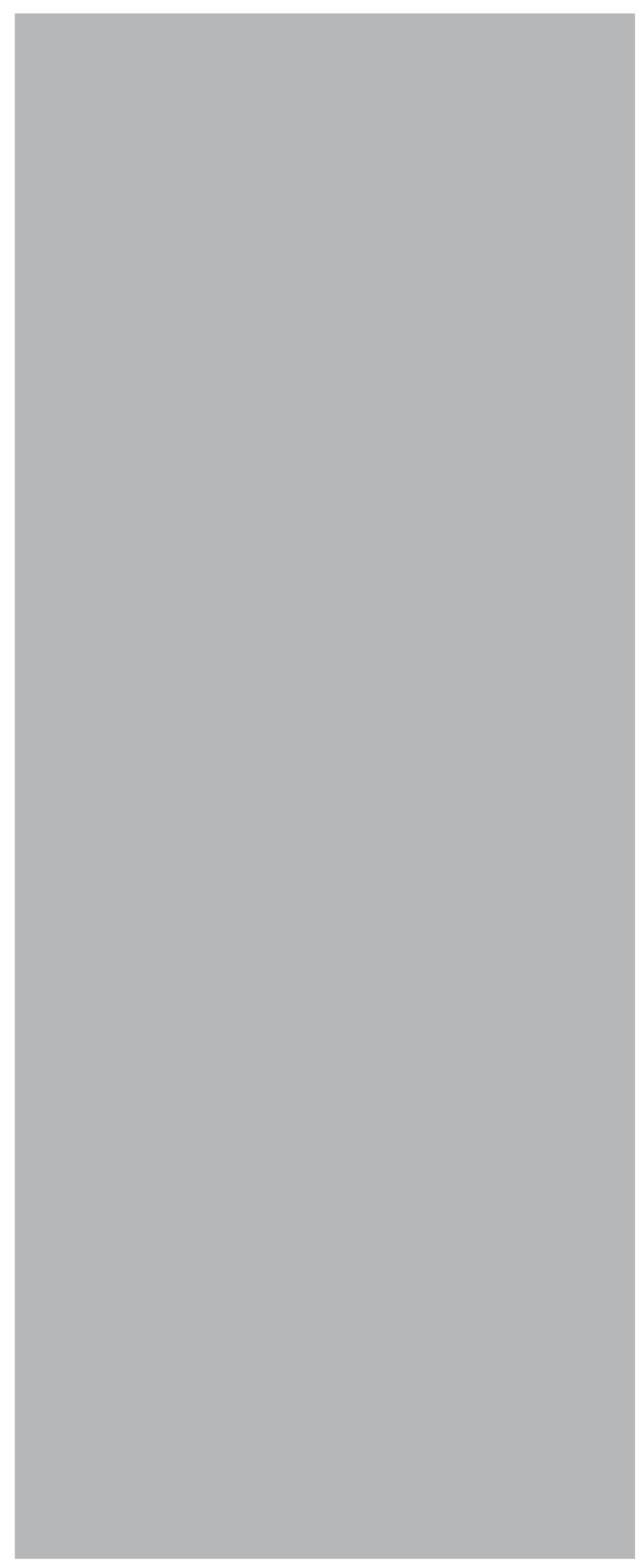

SIMPULAN

Berdasarkan hasil analisis data dan pembahasan hasil yang telah dijabarkan, maka hasil penelitian dapat disimpulkan bahwa secara simultan maupun secara parsial DAU dan PAD berpengaruh signifikan terhadap Belanja Daerah. Selanjutnya juga terbukti bahwa flypaper effect tidak terjadi pada Kabupaten dan Kota di Jawa; akan tetapi PAD dan DAU terbukti cenderung menyebabkan peningkatan jumlah Belanja Daerah di tahun berikutnya. Juga terbukti bahwa terdapat pengaruh yang signifikan dari $\mathrm{DAU}_{\mathrm{t}-1}$ dan $\mathrm{PAD}_{\mathrm{t}-1}$ yang cenderung menyebabkan peningkatan jumlah Belanja Operasi maupun Belanja Modal di tahun berikutnya.

Implikasi lainnya adalah pemahaman dari pemerintah daerah bahwa dana alokasi tersebut hanya sebagai pemicu kemandirian suatu daerah sebagai langkah awal keberhasilan otonomi. Sehingga dengan alokasi dana tersebut, pemerintah daerah dapat bergerak aktif dalam menggali sumber-sumber pendapatan asli daerah yang berpotensi dapat menaikkan persentase penerimaan PAD dan menurunkan alokasi dari pemerintah

Untuk penelitian selanjutnya diharapkan peneliti memperluas cakupan wilayah penelitian yang antara satu kabupaten dengan kabupaten lainnya memiliki hubungan pertanggungjawaban, sebagai contoh beberapa kabupaten dalam satu provinsi. Hal lain yang dapat diteliti adalah terjadinya flypaper effect yang dibandingkan tiap tahunnya.

\section{DAFTAR PUSTAKA}

Adi, Priyo Hari. 2008. Relevansi Transfer Pemerintah Pusat dengan Upaya Pajak (Studi pada Pemerintah Kabupaten dan Kota Se Jawa). The 2nd National Conference Faculty of Economics Widya Mandala Catholic University. http://lpks1.wima.ac.id/pphks/accurate /makalah/IE7.pdf. Diakses 3 September 2009.

Indriantoro, Nur dan Bambang Supomo. 2002. Metodologi Penelitian Bisnis untuk Akuntansi dan Manajemen. Edisi Pertama. Yogyakarta: BPFE.

Darwanto, dan Yulia Yustika Sari. 2007. Pengaruh Pertumbuhan Ekonomi, Pendapatan Asli 
Daerah, dan Dana Alokasi Umum terhadap Pengalokasian Anggaran Belanja Modal. Makalah disampaikan dalam Simposium Nasional Akuntansi X. Makasar. 26 - 28 Juli 2007.

Glosarium. Flypaper Effect.http://pusatbahasa. diknas.go.id/glosarium/?row $=7700$.

Diakses 17 November 2009.

Halim, Abdul. 2002. Akuntansi Sektor Publik: Akuntansi Keuangan Daerah. Edisi Pertama. Bogor: Salemba Empat.

Kuncoro, Haryo. 2007. Fenomena Flypaper Effect pada Kinerja Keuangan Pemerintah Daerah Kota dan Kabupaten di Indonesia. Makalah disampaikan dalam Simposium Nasional Akuntansi X. Makasar. 26-28 Juli 2007.

Mahsun, Mohamad. Firma Sulistyowati, dan Heribertus Andre Purwanugraha. 2007. Akuntansi Sektor Publik. Edisi Kedua. Yogyakarta: BPFE.

Maimunah, Mutiara. 2006. Flypaper Effect pada Dana Alokasi UMUM (DAU) dan Pendapatan Asli Daerah (PAD) terhadap Belanja Daerah pada Kabupaten/Kota di Pulau Sumatera. Makalah disampaikan dalam Simposium Nasional Akuntansi. Padang. 23 26 Agustus 2006.

Ndadari, Laras Wulan, dan Priyo Hari Adi. 2008. Perilaku Asimetris Pemerintah Daerah terhadap Transfer Pemerintah Pusat. Makalah disampaikan dalam The 2nd National Conference UKWMS. Surabaya. 6 September 2008.

Novianingsih, Betty. 2009. Pengaruh Sumber Pendapatan terhadap Belanja Modal pada Kabupaten/Kota di Pulau Jawa. Skripsi. Sarjana Ekonomi Akuntansi Universitas Jenderal
Soedirman. Purwokerto. (Tidak dipublikasikan).

Al-Firsta, D.W. dan B.A.Pramuka. 2010. Flypaper Effect pada Dana Alokasi Umum (DAU) dan Pendapatan Asli Daerah (PAD) terhadap Belanja Daerah Pada Kabupaten di Karesidenan Banyumas. Skripsi. Sarjana Ekonomi Akuntansi Universitas Jenderal Soedirman. Purwokerto. (Tidak dipublikasikan).

Shinta, Dian Ayu. 2009. Perilaku Asimetris Pemerintah Daerah terhadap Transfer dari Pemerintah Pusat pada Kabupaten/Kota di Jawa Tengah. Skripsi. Sarjana Ekonomi Akuntansi Universitas Jenderal Soedirman. Purwokerto. (Tidak dipublikasikan).

Suliyanto. 2005. Analisis Data dalam Aplikasi Pemasaran. Bogor: Penerbit Ghalia Indonesia.

Supranto, J. 2000. Teknik Sampling Untuk Survey dan Eksperimen. Jakarta: PT Asdi Mahasatya.

Widodo, Pambudi Tri. 2007. Flypaper Effect pada Dana Alokasi UMUM (DAU) dan Pendapatan Asli Daerah (PAD) terhadap Belanja Daerah pada Kabupaten/Kota di Bali. (Studi pada Kabupaten/Kota di Bali). http://rac.uii. ac.id/server/document/Private/200807251 1265203312374.pdf. Diakses 3 September 2009.

Wijaya, Sandhi. 2008. Pengaruh Pendapatan Asli Daerah dan Dana Perimbangan terhadap Besarnya Belanja Daerah (Studi pada Kabupaten se-Karesidenan Pekalongan). Skripsi. Sarjana Ekonomi Akuntansi Universitas Jenderal Soedirman. Purwokerto. (Tidak dipublikasikan). 


\section{LAMPIRAN}

1. Ringkasan Hasil Analisis Statistik $\rightarrow$ Tanpa Lag (Hipotesis 1 \& 2)

\begin{tabular}{|c|c|c|c|c|c|c|}
\hline \multicolumn{7}{|c|}{ Belanja Daerah (Y1) } \\
\hline & \multicolumn{2}{|c|}{ Kabupaten } & \multicolumn{2}{|l|}{ Kota } & \multicolumn{2}{|c|}{ Kabupaten+Kota } \\
\hline R-Square & \multicolumn{2}{|c|}{0,8961549} & \multicolumn{2}{|l|}{0,956294} & \multicolumn{2}{|c|}{0,9274650} \\
\hline Adj. R-Square & \multicolumn{2}{|l|}{0,8948404} & \multicolumn{2}{|l|}{0,954733} & \multicolumn{2}{|l|}{0,9267965} \\
\hline Significance F & \multicolumn{2}{|l|}{0,0000} & \multicolumn{2}{|l|}{0,0000} & \multicolumn{2}{|l|}{0,0000} \\
\hline Partial-test & Coefficients & P-value & Coefficients & P-value & Coefficients & P-value \\
\hline - Intercept & 9891,1501 & 0,65466 & $-59285,38$ & 0,06872 & 5079,91301 & 0,75801 \\
\hline - PAD & 2,066564 & 0,00000 & 1,625477 & 0,00000 & 1,966800 & 0,00000 \\
\hline - DAU & 1,098831 & 0,00000 & 1,457837 & 0,00000 & 1,127870 & 0,00000 \\
\hline \multicolumn{7}{|c|}{ Belanja Modal (Y2) } \\
\hline & \multicolumn{2}{|c|}{ Kabupaten } & \multicolumn{2}{|l|}{ Kota } & \multicolumn{2}{|c|}{ Kabupaten+Kota } \\
\hline R-Square & \multicolumn{2}{|l|}{0,4737293} & \multicolumn{2}{|l|}{0,7050009} & \multicolumn{2}{|l|}{0,5322970} \\
\hline Adj. R-Square & \multicolumn{2}{|l|}{0,4670676} & \multicolumn{2}{|l|}{0,6944653} & \multicolumn{2}{|l|}{0,5279864} \\
\hline Significance F & \multicolumn{2}{|l|}{0,000000} & 0,000000 & & \multicolumn{2}{|l|}{0,000000} \\
\hline Partial-test & Coefficients & P-value & Coefficients & P-value & Coefficients & P-value \\
\hline - Intercept & 10851,1968 & 0,44964 & 28568,9418 & 0,062975 & 20244,8005 & 0,038777 \\
\hline - PAD & 0,69170429 & 0,00000 & 0,29885486 & 0,00003 & 0,3741434 & 0,00003 \\
\hline - DAU & 0,16744123 & 0,00000 & 0,18945638 & 0,000818 & 0,1876747 & 0,000818 \\
\hline \multicolumn{7}{|c|}{ Belanja Operasi (Y3) } \\
\hline & \multicolumn{2}{|c|}{ Kabupaten } & \multicolumn{2}{|l|}{ Kota } & \multicolumn{2}{|c|}{ Kabupaten+Kota } \\
\hline R-Square & \multicolumn{2}{|l|}{0,8865482} & \multicolumn{2}{|l|}{0,9471456} & \multicolumn{2}{|l|}{0,9173863} \\
\hline Adj. R-Square & 0,8851121 & & 0,9452579 & & 0,9166248 & \\
\hline Significance F & 0,000000 & & 0,000000 & & 0,000000 & \\
\hline Partial-test & Coefficients & P-value & Coefficients & P-value & Coefficients & P-value \\
\hline - Intercept & 171,724101 & 0,99257 & $-87995,5771$ & 0,004592 & $-14400,887$ & 0,322659 \\
\hline - PAD & 1,37479754 & 0,00000 & 1,32581373 & 0,00000 & 1,5944623 & 0,00000 \\
\hline - DAU & 0,92699872 & 0,00000 & 1,26801762 & 0,00000 & 0,9362917 & 0,00000 \\
\hline
\end{tabular}

2. Ringkasan Hasil Analisis Statistik $\rightarrow$ Lag-1 (Hipotesis 3 \& 4)

\begin{tabular}{lccrcccc}
\hline & \multicolumn{3}{c}{ Belanja Daerah (Y1) } \\
& \multicolumn{2}{c}{ Kabupaten } & \multicolumn{3}{c}{ Kota } & \multicolumn{2}{c}{ Kabupaten+Kota } \\
\hline R-Square & 0,77094942 & & 0,97897326 & & 0,8767476 & \\
Adj. R-Square & 0,76515067 & & 0,97761669 & & 0,8745661 & \\
Significance F & 0,0000 & & 0,0000 & & 0,0000 & \\
$\quad$ Partial-test & Coefficients & P-value & Coefficients & P-value & Coefficients & P-value \\
- Intercept & 172879,2501 & 0,000217 & $-122184,696$ & 0,00082 & 86903,0264 & 0,005421 \\
- PAD (t-1) & 2,587456561 & 0,00000 & 1,45678913 & 0,00000 & 2,18126179 & 0,0000 \\
- DAU(t-1) & 0,978317648 & 0,00000 & 2,03751226 & 0,00000 & 1,18615999 & 0,0000 \\
\hline
\end{tabular}




\begin{tabular}{|c|c|c|c|c|c|c|}
\hline \multicolumn{7}{|c|}{ Belanja Modal (Y2) } \\
\hline & \multicolumn{2}{|c|}{ Kabupaten } & \multicolumn{2}{|c|}{ Kota } & \multicolumn{2}{|c|}{ Kabupaten+Kota } \\
\hline R-Square & 0.28200434 & & 0.7792176 & & 0.4860383 & \\
\hline Adj. R-Square & 0.26382723 & & 0.7649737 & & 0.4769416 & \\
\hline Significance F & 0.0000021 & & 0.000000 & & 0.000000 & \\
\hline Partial-test & Coefficients & P-value & Coefficients & P-value & Coefficients & P-value \\
\hline - Intercept & 78479.21947 & 0.0003337 & 26640.6574 & 0.19128 & 60528.3949 & 0.00002 \\
\hline - $\operatorname{PAD}(\mathrm{t}-1)$ & 0.632759554 & 0.0009055 & 0.30426661 & 0.00129 & 0.42247717 & 0.00000 \\
\hline - $\mathrm{DAU}(\mathrm{t}-1)$ & 0.107525009 & 0.0140877 & 0.28797184 & 0.00052 & 0.16226750 & 0.00000 \\
\hline \multicolumn{7}{|c|}{ Belanja Operasi (Y3) } \\
\hline & \multicolumn{2}{|c|}{ Kabupaten } & \multicolumn{2}{|c|}{ Kota } & \multicolumn{2}{|c|}{ Kabupaten+Kota } \\
\hline R-Square & 0.79992078 & & 0.9735756 & & 0.8855034 & \\
\hline Adj. R-Square & 0.79485548 & & 0.9718708 & & 0.8834769 & \\
\hline Significance F & 0.000000 & & 0.000000 & & 0.000000 & \\
\hline Partial-test & Coefficients & P-value & Coefficients & P-value & Coefficients & P-value \\
\hline - Intercept & 93906.22465 & 0.00796 & -149621.796 & 0.0000338 & 26415.5419 & 0.285499 \\
\hline - $\operatorname{PAD}(\mathrm{t}-1)$ & 1.955719618 & 0.00000 & 1.15000455 & 0.00000 & 1.76250463 & 0.00000 \\
\hline - $\mathrm{DAU}(\mathrm{t}-1)$ & 0.86700349 & 0.00000 & 1.75092743 & 0.00000 & 1.01915959 & 0.00000 \\
\hline
\end{tabular}

